\title{
ANALISIS PENDAPATAN DAN TINGKAT KESEJAHTERAAN RUMAH TANGGA PETANI NANAS DI DESA ASTOMULYO KECAMATAN PUNGGUR KABUPATEN LAMPUNG TENGAH
}

\author{
(Analysis of Income and Prosperity Grade of Pineapple Farmer's Household in Astomulyo Village Punggur \\ District Central Lampung Regency)
}

Ferentia Aurora, Dwi Haryono, Lina Marlina

Jurusan Agribisnis, Fakultas Pertanian, Universitas Lampung, Jl. Prof. Dr. Soemantri Brodjonegoro No. 1

Bandar Lampung 35145, e-mail:dwi.haryono@fp.unila.ac.id

\begin{abstract}
This research aims to analyze pineapple farming income, household income, and the prosperity grade of pineapple farmer's household in Astomulyo Village. This research was purposively conducted in FebruaryMarch 2019 at Astomulyo Village, Punggur Sub District, Central Lampung Regency by survey method. There are 63 respondents taken by Simple Random Sampling. The data was analyzed quantitative and qualitative by farming income method (R/C ratio), household income based on the criteria of BPS (2016), and the welfare level of farmer's household based on the criteria of BPS (2014). The results showed that average income of pineapple farmers based on cash cost and total cost per hectare wasRp46.526.933,00/year and Rp29.502.072,00/year. Pineapple farming was beneficial because it gained acceptance ratio with cash cost and total cost more than one $(R / C$ ratio) as 3.33 and 1.80 . The household income of pineapple farmers was categorized as high income for it reached Rp4.000.000,00/month until Rp6.000.000,00/month. The most contributed income was derived from pineapple farming activities $(66.49 \%)$, the others were from off farming $(13.74 \%)$, non-pineapple on farming $(12.39 \%)$, and nonfarming activities (7.37\%). Based on BPS criteria, $50.79 \%$ pineapple farmers household in Astomulyo Village were categorized in not prosperous and $49.21 \%$ as prosperous farmers household.
\end{abstract}

Key words: household income, pineapple, prosperity grade

\section{PENDAHULUAN}

Sektor pertanian merupakan salah satu sektor yang memiliki peranan penting dalam meningkatkan perekonomian di Indonesia yang dijadikan sebagai sumber mata pencaharian utama oleh sebagian besar masyarakat Indonesia. Menurut Badan Pusat Statistik (2017), Produk Domestik Bruto Indonesia dari sektor pertanian menempati urutan pertamasebesar 13,14 persen dibandingkan dengan sektor yang lainnya. Tingginya kontribusi sektor pertanian harus dipertahankan dengan tetap melakukan pembangunan pertanian karena produk pertanian memiliki peranan penting dalam penyediaan bahan pangan, bahan baku industri, peningkatan ekspor dan devisa negara, penyediaan kesempatan kerja, dan peningkatan kesejahteraan.

Sektor pertanian terdiri dari banyak subsektor, salah satunya subsektor hortikultura.Subsektor hortikultura terdiri dari tanaman buah-buahan dan sayuran. Buah-buahan memiliki prospek yang baik untuk dikembangkan mengingat bahwa masyarakat semakin sadar akan pentingnya mengkonsumsi buah-buahan.Buah nanas dapat ditemukan dengan mudah di setiap daerah di
Indonesia.Selain untuk dikonsumsi di dalam negeri, buah nanas di Indonesia juga diekspor keluar negeri.

Provinsi Lampung merupakan salah satu sentra produksi buah nanas yang memberikan kontribusi besar bagi produksi nanas di Indonesia, yaitu sebesar 33 persen, diikuti oleh Provinsi Sumatera Utara, Provinsi Jawa Barat, Provinsi Jambi, Provinsi Jawa Timur, Provinsi Jawa Tengah, dan yang lainnya (Badan Pusat Statistik 2016a). Produksi nanas di Provinsi Lampung pada tahun 2013 hingga 2016 terus mengalami penurunan, akan tetapi pada tahun 2017 produksi nanas mengalami peningkatan sebesar 6 persen (Badan Pusat Statistik Provinsi Lampung 2017).

Kabupaten Lampung Tengah merupakan sentra produksi nanas di Provinsi Lampung dengan jumlah produksi nanas tertinggi pada tahun 2017 mencapai 99,88 persen. Budidaya nanas di Kabupaten Lampung Tengah terbagi menjadi dua macam yaitu budidaya oleh perusahaan dan budidaya oleh rakyat.Sentra nanas rakyat terletak di Kecamatan Punggur dengan jumlah produksi berfluktuasi pada tahun 2015 hingga tahun 
2017.Pada tahun 2017, produksi nanas di Kecamatan Punggur menempati urutan kedua yaitu mencapai 159.312 kuintal setelah Kecamatan Terbanggi Besar, meskipun berdasarkan rata-rata produksi per tahunnya Kecamatan Punggur berada pada urutan pertama dalam produksi nanas, yaitu sebesar 4.743.629 kuintal/tahun (Badan Pusat StatistikKabupaten Lampung Tengah 2017).

Desa Astomulyo merupakan salah satu desa yang dijadikan sebagai sentra nanas di Kecamatan Punggur dengan luas lahan mencapai 350 ha.Tahun 2013 hingga tahun 2017, produksi nanas di Desa Astomulyo mengalami fluktuasi. Meskipun mengalami fluktuasi, rata-rata produksi nanas per tahunnya paling tinggi sebesar 12.654 ton/tahun dibandingkan dengan desa yang lainnya (BPPP Kecamatan Punggur 2017).

Petani nanas di Desa Astomulyo pada mulanya adalah petani padi. Akan tetapi petani memutuskan untuk beralih komoditas sekitar tahun 1990-an karena beberapa faktor. Faktor-faktor tersebut antara lain menanam nanas lebih mudah dan menguntungkan dibandingkan dengan menanam padi, harga nanas yang relatif stabil, dan proses pemasarannya lebih mudah. Jenis nanas yang diusahakan oleh petani nanas di Desa Astomulyo adalah nanas batu.

Berdasarkan hasil survai, petani nanas juga dihadapkan pada keterbatasan sarana produksi seperti pupuk yang sulit didapat, teknologi budidaya yang digunakan masih sederhana, modal yang terbatas, dan serangan penyakit yang belum dapat diatasi. Kondisi ini akan mempengaruhi tingkat pendapatan dan kemampuan petani nanas dalam mencukupi kebutuhan dasar rumah tangganya. Menurut Badan Pusat Statistik Kabupaten Lampung Tengah (2017) masih terdapat 5.710 keluarga yang termasuk dalam golongan keluarga pra sejahtera di Kecamatan Punggur. Hal ini menggambarkan bahwa mayoritas masyarakat di Kecamatan Punggur yang bekerja sebagai petani dikatakan masih belum sejahtera dan belum mampu memenuhi kebutuhan dasarnya. Tentu ini memberikan pertanyaan bahwa sektor pertanian sebagaimana mata pencaharian utama mereka masih tidak dapat menjamin keberlangsungan hidup untuk taraf yang lebih baik. Berdasarkan permasalahan diatas, maka penelitian ini bertujuan untuk menganalisis pendapatan usahatani nanas, pendapatan rumah tangga petani nanas, dan tingkat kesejahteraan rumah tangga petani nanas di Desa Astomulyo, Kecamatan Punggur, Kabupaten Lampung Tengah.

\section{METODE PENELITIAN}

Penelitian dilakukan dengan metode survai. Penelitian dilakukan di Kecamatan Punggur, Kabupaten Lampung Tengah yang dipilih secara sengaja (purposive) karena Kecamatan Punggur merupakan sentra nanas rakyat. Pengambilan data dilaksanakan padabulan Februari hingga Maret 2019.

Responden penelitian adalah petani yang membudidayakan tanaman nanas dan mengolah hasil panen nanas yang berada pada satu desa yaitu Desa Astomulyo yang dipilih secara purposive dengan alas an karena Desa Astomulyo merupakan sentra penghasil nanas dari 9 desayang ada di Kecamatan Punggur. Populasi petani nanas di Desa Astomulyo sebanyak 362 petani. Metode pangambilan sampel dilakukan dengan menggunakan metode acak sederhana (simple random sampling). Penentuan jumlah sampel mengacu pada Sugiarto (2003) sehingga diperoleh jumlah sampel sebanyak 63 rumah tangga petani nanas.

Data yang digunakan dalam penelitian berupa data primer dan data sekunder. Data primer diperoleh dari wawancara langsung dengan petani nanas menggunakan kuisioner seperti jumlah penggunaan sarana produksi, hasil produksi, pendapatan rumah tangga petani dan tingkat kesejahteraan. Data sekunder berupa volume ekspor nanas, jumlah produksi nanas di Provinsi Lampung, Kabupaten Lampung Tengah, dan Kecamatan Punggur yang diperoleh dari lembaga atau instansi terkait penelitian seperti Badan Pusat Statistik, Kementrian Pertanian, BPPP Kecamatan Punggur, dan lain-lain. Metode analisis data yang digunakan dalam penelitian ini yaitu analisis kuantitatif dan kualitatif. Analisis kuantitatif digunakan untuk mengetahui besarnya pendapatan usahatani nanas dan pendapatan rumah tangga, sedangkan analisis kualitatif digunakan untuk menggambarkan tingkat kesejahteraan rumah tangga petani nanas di Desa Astomulyo.

Pendapatan usahatani diperoleh dengan menghitung selisih antara penerimaan yang diperoleh dari hasil usahatani dengan biaya produksi yang dikeluarkan selama tahun 2018, untuk mengetahui pendapatan petani digunakan rumus (Soekartawi 1994) :

$\pi=\mathrm{Y} . \mathrm{Py}-\mathrm{Xi} . \mathrm{Pxi}$ 
Keterangan :

$\pi \quad=$ Keuntungan

$\mathrm{Y} \quad=$ Produksi $(\mathrm{kg})$

Py $=$ Harga hasil produksi $(\mathrm{Rp})$

$\mathrm{Xi} \quad=$ Faktor produksi, $\mathrm{i}=1,2,3,4, \ldots \ldots, \mathrm{n}$

Pxi $=$ Harga faktor produksi (Rp)

Penerimaan usahatani per satuan biaya yang dikeluarkan dapat dilihat dengan menggunakan indikator Revenue Cost Ratio (R/C). Nilai nisbah penerimaan dan biaya dapat diperoleh dari rumus (Soekartawi 1995) :

$\mathrm{R} / \mathrm{C}=\frac{\mathrm{TR}}{\mathrm{TC}}$

Keterangan :

$\mathrm{R} / \mathrm{C}=$ Nisbah antara penerimaan dan biaya

$\mathrm{TR}=$ Total penerimaan (total revenue)

$\mathrm{TC}=$ Total biaya (total cost)

Pengambilan keputusan adalah :

a. Jika $\mathrm{R} / \mathrm{C}>1$, maka usahatani yang dilakukan layak atau menguntungkan.

b. Jika $\mathrm{R} / \mathrm{C}=1$, maka usahatani yang dilakukan berada pada titik impas (Break Even Point).

c. Jika $\mathrm{R} / \mathrm{C}<1$, maka usahatani yang dilakukan tidak layak atau tidak menguntungkan petani.

\section{Analisis Pendapatan Rumah Tangga}

Pendapatan rumah tangga diperoleh dengan cara menjumlahkan pendapatan keluarga yang berasal dari usahatani nanas, usahatani bukan nanas, non usahatani, dan luarpertanian. Pendapatan rumah tangga petani diketahui dengan menggunakan rumus (Hastuti dan Rahim 2008) :

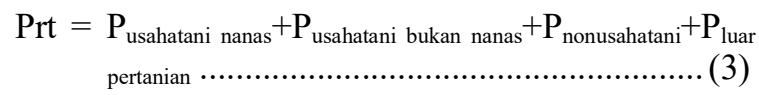

Keterangan:

$\begin{array}{llll}\text { Prt } & \text { Pendapatan rumah tangga } \\ \mathrm{P}_{\text {usahatani nanas }} & =\begin{array}{l}\text { Pendapatan dari usahatani } \\ \text { nanas }\end{array} \\ \mathrm{P}_{\text {usahatani bukan nanas }}= & \begin{array}{l}\text { Pendapatan dari usahatani } \\ \text { bukan nanas }\end{array} \\ \mathrm{P}_{\text {nonusahatani }}= & \begin{array}{l}\text { Pendapatan } \\ \text { usahatani }\end{array} \\ \mathrm{P}_{\text {luar pertanian }}= & \text { Pendapatan dari luarpertanian }\end{array}$

Menurut BPS (2016), pendapatan digolongkan menjadi 4 sebagai berikut :

1. Golongan pendapatan sangat tinggi, jika pendapatan rata- rata lebih dari Rp6.000.000,00 per bulan.
2. Golongan pendapatan tinggi, jika pendapatan rata-rata antara Rp4.000.000,00 hingga Rp6.000.000,00 per bulan.

3. Golongan pendapatan sedang, jika pendapatan rata-rata antara $\mathrm{Rp} 2.000 .000,00$ hingga Rp4.000.000,00 per bulan.

4. Golongan pendapatan rendah, jika pendapatan rata-rata Rp2.000.000,00 per bulan.

\section{Analisis Kesejahteraan Rumah Tangga}

Metode analisis untuk mengukur tingkat kesejahteraan rumah tangga petani nanas menggunakan indikator BPS (2014).Indikator yang digunakan yaitu kependudukan, kesehatan dan gizi, pendidikan, ketenagakerjaan, taraf dan pola konsumsi, perumahan dan lingkungan, sosial dan lain-lain.Klasifikasi kesejahteraan yang digunakan terdiri dari dua klasifikasi yaitu petani dalam kategori sejahtera dan belum sejahtera. Klasifikasi tersebut ditentukan dengan cara mengurangkan skor tertinggi dengan jumlah skor terendah kemudian hasilnya dibagi dengan jumlah klasifikasi dari indikator yang digunakan. Rumus penentuan range skor (BPS 2014) sebagai berikut :

$\mathrm{RS}=\frac{\mathrm{SkT}-\mathrm{SkR}}{\mathrm{JK} 1}$

Keterangan :

$\mathrm{RS}=$ Range skor

SkT $=$ Skor tertinggi $(7 \times 3=21)$

SkR $=$ Skor terendah $(7 \mathrm{x} 1=7)$

JK1 = Jumlah klasifikasi yang digunakan (2)

Hasil perhitungan tersebut diperoleh range skor (RS) sehingga tingkat kesejahteraan rumah tangga petani nanas yaitu :

1. Jika skor antara 7-14 berarti rumah tangga petani belum sejahtera.

2. Jika skor antara15-21 berarti rumah tangga petani sejahtera.

\section{HASIL DAN PEMBAHASAN}

\section{Keadaaan Umum Petani Responden}

Berdasarkan hasil penelitian yang dilakukan diperoleh umur responden terbanyakantara 45-49 tahun (41,27\%). Menurut Mantra (2004) umur produsen tergolong ke dalam usia produktif untuk melakukan pekerjaan dengan baik. Tingkat pendidikan sebagian besar petani nanas ialah lulusan SD dengan jumlah 28 orang $(44,44 \%)$. Sementara jumlah tanggungan keluarga petani berada pada kisaran antara 3 sampai 4 orang 
$(63,49 \%)$. Hal ini menandakan jumlah anggota keluarga yang harus ditanggung cukup banyak. Mayoritas 85,71 persen petani nanas memiliki pengalaman berusahatani nanas berkisar antara 1120 tahun. Hal ini menunjukkan petani nanas responden memiliki pengalaman yang cukup dalam berusahatani dan terampil dalammelakukan kegiatan usahatani. Sebagian besar petani nanas di Desa Astomulyo memiliki luas lahan antara 0,250,50 ha $(53,97 \%)$. Dalam melakukan usahatani nanas, seluruh petani nanas di Desa Astomulyo menggunakan modal sendiri.

\section{Keragaan Usahatani}

Pola tanam yang digunakan petani nanas responden selama satu musim tanam (dalam waktu dua tahun) yaitu monokultur. Pemanenan nanas dilakukan setiap tahun selama musim tanamnya. Jarak tanam yang diterapkan petani $1 \mathrm{~m} \times 0,25 \mathrm{~m}$ sehingga mampu menampung tanaman nanas sebanyak 40.000 rumpun per hektar. Tahap-tahap budidaya nanas yaitu (1) penyiangan dan pemupukan sebelum pengolahan lahan, (2) pengolahan lahan, (3) penanaman, (4) pemupukan sebanyak 3 kali, (5) penyiangan, (6) pemberantasan hama dan penyakit, (7) pengkarbitan, (8) panen dan pengangkutan, dan (9) pengelompokan.

\section{Penggunaan Sarana Produksi}

Bibit yang digunakan oleh petani nanas responden seluruhnya adalah bibit nanas golongan Queen dengan jenis varietasnya yaitu nanas batu, berasal dari lahan mereka sendiri dan pembelian. Bibit nanas yang dibeli oleh petani nanas sebesar 3.138 batang/0,74 ha atau 4.241 batang/ha sedangkan penggunaan bibit yang berasal dari lahan petani sebesar 26.782 batang $/ 0,74$ ha atau 36.192 batang/ha. Pembelian bibit bertujuan untuk memenuhi kekurangan jumlah bibit yang akan ditanam sehingga memenuhi anjuran Balai Penelitian Tanaman Buah Tropika (2008) sebanyak $38.000-40.000$ batang per hektar.

Pupuk yang digunakan oleh petani nanas yaitu pupuk kandang, urea, phonska, SP-36, mutiara, dan prothephon. Penggunaan pupuk urea, phonska dan prothephon berada diatas anjuran Balai Penelitian Tanaman Buah Tropika (2008), sedangkan penggunaan pupuk yang lainnya sudah sesuai dengan anjuran. Pestisida yang digunakan petani yaitu jenis herbisida dengan merk dagang Gramaxone, Naparon, dan Sidaron. Seluruh petani menggunakan Gramaxone karena dianggap sangat ampuh dalam mengendalikan gulma. Petani nanas di Desa Astomulyo lebih banyak menggunakan tenaga kerja luar keluarga dibandingkan dengan tenaga kerja dalam keluarga. Peralatan yang digunakan petani dalam berusahatani nanas yaitu cangkul, arit, handsprayer, dan sarung tangan.

\section{Produksi, Penerimaan, dan Biaya Usahatani Nanas}

Nanas di Desa Astomulyo dapat dipanen sebanyak 2 kali dari satu musim tanam selama 2 tahun. Produksi nanas hanya dihitung dari jumlah produksi pada tahun pertama yang digolongkan menjadi 3 jenis yaitu Grade A, B, dan C dengan harga yang berbeda-beda. Rata-rata dari ketiga jenis tersebut sebesar 25,902 ton/ha sedangkan rata-rata penerimaan sebesar Rp66.474.876/ha. Biaya tunai yang dikeluarkan petani nanas dalam satu tahun yaitu bibit, pupuk, pestisida, TKLK, pembelian sarung tangan, pajak, dan sewa mobil angkut. Biaya diperhitungkan yang dikeluarkan petani yaitu bibit, TKDK, penyusutan alat, dan sewa lahan. Rata-rata total biaya produksi nanas sebesar Rp36.972.804,00/ha. Biaya yang paling banyak dikeluarkan oleh petani yaitu biaya pupuk dan biaya bibit diperhitungkan, sedangkan biaya pembelian sarung tangan paling sedikit dikeluarkan oleh petani.

\section{Pendapatan Rumah Tangga Petani Nanas}

Pendapatan rumah tangga petani nanas berasal dari pendapatan usahatani nanas, pendapatan usahatani bukan nanas, pendapatan non usahatani, dan pendapatan dari luar pertanian. Pendapatan usahatani berasal dari selisih antara penerimaan dengan biaya yang dikeluarkan.

Berdasarkan Tabel 3 (terlampir) dapat diketahui pendapatan usahatani nanas atas biaya total per ha sebesar Rp44.323.593,00/tahun sedangkan ratarata biaya total yang dikeluarkan petani sebesar Rp36.972.804,00/tahun. Nilai $\mathrm{R} / \mathrm{C}$ atas biaya tunai dan biaya total usahatani nanas masing-masing sebesar 3,33 dan 1,80. Hal ini menunjukkan bahwa usahatani nanas menguntungkan untuk diusahakan. Nilai $\mathrm{R} / \mathrm{C}$ atas biaya tunai sebesar 3,33 berarti setiap Rp1.000,00 biaya tunai yang dikeluarkan petani dapat menghasilkan penerimaan sebesar Rp3.330,00, sedangkan nilai $\mathrm{R} / \mathrm{C}$ atas biaya total sebesar 1,80 berarti bahwa setiap Rp1.000,00 biaya total yang dikeluarkan petani dapat menghasilkan penerimaan sebesar Rp1.800,00. Penelitian ini sejalan dengan 
penelitian Astuti, Affandi, dan Kalsum (2010) yang menunjukkan usahatani nanas tergolong menguntungkan dengan nilai $\mathrm{R} / \mathrm{C}$ atas biaya tunai sebesar 3,66 dan nilai $\mathrm{R} / \mathrm{C}$ atas biaya total sebesar 1,58 .

Selain berusahatani nanas, petani juga melakukan usahatani lainnya seperti usahatani padi, singkong, dan bibit lele. Pendapatan petani nanas dari usahatani bukan nanas sebesar Rp6.416.586,00/ tahun dengan kontribusi terbesar dari pendapatan usahatani padi dengan persentase 69,46 persen (34 orang) dan kontribusi terkecil berasal dari usahatani singkong dengan persentase 9,76 persen (6 orang).

Pendapatan diluar kegiatan budidaya nanas (off farm) berasal dari tengkulak nanas dan buruh tani. Rata-rata pendapatan off farm sebesar Rp7.116.667,00/tahun. Petani nanas lebih banyak memilih bekerja menjadi buruh tani (27 orang) dengan rata-rata jumlah pendapatan sebesar Rp5.588.889,00/tahun (78,53\%) dibandingkan bekerja menjadi tengkulak (3 orang) dengan ratarata jumlah pendapatan sebesar Rp1.527.778,00/ tahun $(21,47 \%)$. Hal ini karena tidak semua petani responden memiliki modal yang cukup dan pengetahuan dalam berbisnis.

Pendapatan dari usaha nonpertanian (nonfarm) berasal dari kepala dusun, berdagang (warung), dan buruh bangunan. Rata-rata pendapatan nonfarm sebesar Rp3.815.476,00/tahun. Petani nanas lebih banyak memilih berdagang (warung) (9 orang) yang memberikan kontribusi terbesar bagi pendapatan rumah tangga sebesar Rp3.447.222,00 (90,35\%). Kontribusi lainnya berasal dari kepala dusun(2 orang) dengan rata-rata jumlah pendapatan sebesar Rp285.714,00/tahun (7,49\%) dan buruh bangunan (2 orang) dengan rata-rata jumlah pendapatan sebesar Rp82.540,00/ tahun $(2,16 \%)$.

Pendapatan rumah tangga petani nanas tidak hanya berasal dari sektor pertanian (pendapatan usahatani nanas, pendapatan usahatani bukan nanas, dan pendapatan non usahatani) tetapi juga berasal dari sektor non pertanian.Rata-rata pendapatan rumah tangga petani nanas per tahun dapat dilihat pada Tabel 1.

Berdasarkan Tabel 1,pendapatan usahatani nanas memberikan kontribusi terbesar bagi pendapatan rumah tangga sebesar 66,49 persen dengan ratarata pendapatan Rp34.429.930,00/tahun artinya usahatani nanas memiliki peranan penting dalam menjaga keberlangsungan hidup petani responden. Sementara itu, pendapatan rumah tangga petani responden terkecil berasal dari kegiatan usaha nonpertanian (nonfarm) yaitu hanya sebesar 7,37 persen dengan rata-rata pendapatan Rp3.815.476,00/tahun.

Hal ini dikarenakan tidak semua petani responden memiliki kegiatan lain di luar pertanian sebagai sumber pendapatan petani. Kontribusi pendapatan rumah tangga petani nanas di Desa Astomulyo lebih banyak berasal dari sektor pertanian sebesar 92,63 persen dibandingkan dengan sektor nonpertanian sebesar 7,37 persen.Hal ini sejalan dengan penelitian Marlina, Dharmawan, dan Purnamadewi (2017) yang menunjukkan sumber pendapatan rumah tangga petani lebih banyak berasal dari pertanian (on farm dan off farm) dibandingkan dengan sektor nonpertanian (nonfarm).

Berdasarkan penggolongan pendapatan menurut BPS (2016b), pendapatan rumah tangga petani nanas di Desa Astomulyo termasuk ke dalam golongan pendapatan tinggi dengan rata-rata pendapatan rumah tangga petani nanas sebesar Rp4.314.888,00/bulan. Menurut BPS (2016) jika rata-rata pendapatan per bulan antara Rp4.000.000,00/bulan-Rp6.000.000,00/bulan maka pendapatan tersebut tergolong ke dalam pendapatan tinggi. Penelitian ini sejalan dengan penelitian Pranata, Widjaya, dan Silviyanti (2018) yang menunjukkan pendapatan rumah tangga petani lada menurut penggolongan pendapatan BPS (2014) tergolong tinggi dengan rata-rata pendapatan per bulan antara Rp2.500.000,00/bulan hingga Rp3.500.000,00/bulan.

Tabel 1. Rata-rata pendapatan rumah tangga petani nanas per tahun

\begin{tabular}{|c|c|c|c|}
\hline No. & Sumber pendapatan & $\begin{array}{l}\text { Pendapatan } \\
\text { (Rp) }\end{array}$ & Persentase \\
\hline 1. & $\begin{array}{l}\text { Pendapatan dari } \\
\text { usahatani nanas (on farm } \\
\text { utama) }\end{array}$ & 34.429 .930 & 66,49 \\
\hline 2. & $\begin{array}{l}\text { Pendapatan dari } \\
\text { usahatani bukan nanas } \\
\text { (on farm bukan utama) }\end{array}$ & 6.416 .587 & 12,39 \\
\hline 3. & $\begin{array}{l}\text { Pendapatan dari kegiatan } \\
\text { di luar budidaya (off } \\
\text { farm) }\end{array}$ & 7.116 .667 & 13,74 \\
\hline 4. & $\begin{array}{l}\text { Pendapatan dari usaha } \\
\text { non pertanian (non farm) }\end{array}$ & 3.815 .476 & 7,37 \\
\hline & Jumlah & 51.778 .660 & 100,00 \\
\hline
\end{tabular}




\section{Tingkat Kesejahteraan Rumah Tangga Petani Nanas}

Kriteria tingkat kesejahteraan menurut BPS (2014) menggunakan 7 indikator antara lain kependudukan, kesehatan dan gizi, pendidikan, ketenagakerjaan, taraf dan pola konsumsi, perumahan dan lingkungan, sosial dan lain-lain. Tingkat kesejahteraan rumah tangga petani dikelompokkan menjadi 2 kategori yaitu rumah tangga petani belum sejahtera jika skor yang diperoleh antara 7-14 dan rumah tangga sejahtera jika skor yang diperoleh antara 15-21.

Berdasarkan Tabel 2, dua indikator berada pada kategori baik, 3 indikator berada pada kategori cukup dan 2 indikator berada pada kategori kurang. Indikator perumahan dan lingkungan dengan indikator taraf dan pola konsumsi tergolong pada kategori baikdengan skor yang tinggi yaitu 3.Indikator kependudukan, ketenagakerjaan, kesehatan dan gizi tergolong pada kategori cukup dengan nilai skor 2 . Indikator pendidikan dan sosial tergolong ke dalam kategori kurang karena memiliki nilai skor rendah yaitu 1 . Skor dari setiap indikator kesejahteraan kemudian dijumlahkan sehingga diperoleh total skor yang menunjukkan rumah tangga petani nanas termasuk ke dalam golongan sejahtera atau belum sejahtera.

Hasil perhitungan menunjukkan sebagian besar rumah tangga petani nanas di Desa Astomulyo tergolong ke dalam rumah tangga petani belum sejahterasebanyak 32 petani $(50,79 \%)$ dengan total skor antara 7-14 sedangkan sisanya sebanyak 31 petani $(49,21 \%)$ tergolong ke dalam rumah tangga petani sejahtera dengan total skor antara 15-21. Hal ini tidak sejalan dengan penelitian yang dilakukan oleh Togatorop, Haryono, dan Rosanti (2014) yang menunjukkan rumah tangga petani lada di Kecamatan Gunung Labuhan termasuk dalam kategori sejahtera sebesar 95,2 persen dan sisanya 4,8 persen termasuk dalam kategori belum sejahtera.

Hal lain yang menunjukkan rumah tangga petani belum sejahtera dikarenakan petani tidak memiliki pekerjaan tambahan. Dalam melakukan usahatani nanas hanya bekerja selama kurang dari 30 jam dalam seminggu sehingga petani lebih banyak menganggur dan upah yang diterima petani berupa uang juga belum sesuai. Pendapatan per kapita per tahun rumah tangga petani nanas di Desa Astomulyo juga lebih rendah jika dibandingkan dengan pendapatan per kapita per tahun Kabupaten Lampung Tengah.
Tabel 2. Indikator kesejahteraan BPS 2014

\begin{tabular}{|c|c|c|c|c|}
\hline No. & Indikator & $\begin{array}{l}\text { Jumlah } \\
\text { (orang) }\end{array}$ & $\begin{array}{c}\text { Persenta } \\
\text { se (\%) }\end{array}$ & Kategori \\
\hline 1. & Kependudukan & 60 & 95,24 & Cukup \\
\hline 2. & $\begin{array}{l}\text { Kesehatan dan } \\
\text { Gizi }\end{array}$ & 39 & 61,90 & Cukup \\
\hline 3. & Pendidikan & 61 & 96,83 & Kurang \\
\hline 4. & Ketenagakerjaan & 61 & 96,83 & Cukup \\
\hline 5. & $\begin{array}{l}\text { Taraf dan Pola } \\
\text { Konsumsi }\end{array}$ & 35 & 55,56 & Baik \\
\hline 6. & $\begin{array}{l}\text { Perumahan dan } \\
\text { Lingkungan }\end{array}$ & 63 & 100,00 & Baik \\
\hline 7 & Sosial dll & 41 & 65,08 & Kurang \\
\hline
\end{tabular}

\section{KESIMPULAN}

Pendapatan petani nanas atas biaya tunai per hektar sebesar Rp46.526.933,00/tahun dan pendapatan atas biaya total sebesar Rp29.502.072,00/tahun. Usahatani nanas di Desa Astomulyo menguntungkan dengan nilai $\mathrm{R} / \mathrm{C}$ atas biaya tunai sebesar 3,33 dan nilai $\mathrm{R} / \mathrm{C}$ atas biaya total sebesar 1,80 . Pendapatan rumah tangga petani nanas di Desa Astomulyo tergolong sebagai pendapatan yang tinggi sebesar Rp4.314.888,00/bulan dengan kontribusi terbesar berasal dari sektor pertanian $(92,63 \%)$ dan sektor nonpertanian $(7,37 \%)$. Rumah tangga petani nanas di Desa Astomulyo lebih banyak belum sejahtera sebesar 50,79 persen dibandingkan dengan rumah tangga petani yang sejahtera sebesar 49,21 persen.

\section{DAFTAR PUSTAKA}

Astuti M, Affandi I, dan Kalsum U. 2010. Analisis Pendapatan dan Perilaku Petani Dalam Menghadapi Risiko Usahatani Nanas (Ananas comosus (L.)Merr) di Desa Astomulyo, Kecamatan Punggur, Kabupaten Lampung Tengah. Skripsi. Jurusan Sosial Ekonomi Pertanian Fakultas Pertanian Universitas Lampung. Bandar Lampung.

Balai Penelitian Tanaman Buah Tropika. 2008. Budidaya Nenas. Balai Penelitian Tanaman Buah Tropika. Sumatera Barat.

Badan Pusat Statistik. 2014. Indikator Kesejahteraan Rakyat 2014. BPS.Jakarta.

BPS [Badan Pusat Statistik]. 2016a. Outlook Nanas 2016. BPS. Jakarta. 2016b. Penggolongan Pendapatan Penduduk. BPS. Jakarta. . 2017. Laju Implisit PDB Atas Harga Konstan Tahun 2017. BPS. Jakarta.

BPS [Badan Pusat Statistik] Provinsi Lampung. 2017. Provinsi Lampung Dalam Angka 
2017. BPS Provinsi Lampung. Provinsi Lampung.

BPS [Badan Pusat Statistik] Kabupaten Lampung Tengah. 2017. Kabupaten Lampung Tengah Dalam Angka 2017. BPS Kabupaten Lampung Tengah. Kabupaten Lampung Tengah.

BPPP [Balai Penyuluhan Pertanian dan Perikanan] Kecamatan Punggur. 2017. Kecamatan Punggur Dalam Angka 2017. BPP Kecamatan Punggur. Kecamatan Punggur.

Hastuti DHD dan Rahim ABD. 2008. Pengantar, Teori, dan Kasus Ekonomik Pertanian. Penebar Swadaya. Jakarta.

Mantra IB. 2004. Demografi Umum. Pustaka Pelajar. Yogyakarta.

Marlina L, Dharmawan A, dan Purnamadewi Y. 2017. Peranan kopi rakyat terhadap perekonomian wilayah Kabupaten Lampung Barat. JIIA, 5(3): 292-303. http://jurnal.fp.unila.ac.id/index.php/JIA/art icle/view/1759/1559.[21 November 2018].

Pranata Y, Widjaya S, dan Silviyanti S. 2018. Pendapatan dan tingkat kesejahteraan rumah tangga petani lada di Kecamatan Tanjung Raja, Kabupaten Lampung Utara. JIIA, 5(3): 235-241. http://jurnal.fp.unila. ac.id/index.php/JIA/article/view/920/850. [21 November 2018].

Soekartawi. 1994. Teori Ekonomi Produksi: Dengan Pokok Bahasan Analisis Fungsi Cobb-Douglass. Raja Grafindo Persada. Jakarta.

Soekartawi. 1995. Analisis Usahatani. UI Press. Jakarta.

Sugiarto. 2003. Teknik Sampling. Gramedia. Jakarta.

Togatorop S, Haryono D, dan Rosanti N. 2014. Pendapatan dan tingkat kesejahteraan petani lada di Kecamatan Gunung Labuhan Kabupaten Way Kanan. JIIA, 2(3) : 268-275. http://jurnal.fp.unila.ac.id/index.php/JIA/arti cle/view/810/740. [21 November 2018]. 
JIIA, VOLUME 8 No. 1, FEBRUARI 2020

Tabel 3. Rata-rata penerimaan, biaya, dan R/C usahatani nanas di Desa Astomulyo, 2019

\begin{tabular}{|c|c|c|c|c|c|c|}
\hline \multirow{2}{*}{ Uraian } & \multirow{2}{*}{ Satuan } & \multirow{2}{*}{ Harga (Rp) } & \multicolumn{2}{|c|}{ Per usahatani $(0,74$ ha $)$} & \multicolumn{2}{|c|}{ Per hektar } \\
\hline & & & Jumlah & Total (Rp) & Jumlah & Total (Rp) \\
\hline 1.Penerimaan & & & & 49.191 .408 & & 66.474 .876 \\
\hline Produksi nanas Grade A & $\mathrm{Kg}$ & 3.237 & 8.513 & 27.551 .416 & 11.504 & 37.231 .643 \\
\hline Produksi nanas Grade B & $\mathrm{Kg}$ & 2.157 & 7.149 & 15.419 .022 & 9.661 & 20.836 .517 \\
\hline Produksi nanas Grade C & $\mathrm{Kg}$ & 1.775 & 3.506 & 6.220 .970 & 4.737 & 8.406 .716 \\
\hline \multicolumn{7}{|l|}{ 2. Biaya Produksi } \\
\hline \multicolumn{7}{|l|}{ Biaya Tunai } \\
\hline a. Bibit & Batang & 410 & 3.138 & 1.285 .287 & 4.241 & 1.736 .875 \\
\hline \multicolumn{7}{|l|}{ b. Pupuk } \\
\hline 1. Pupuk Kandang & $\mathrm{Kg}$ & 333 & 5.039 & 1.678 .082 & 6.810 & 2.267 .679 \\
\hline 2. Pupuk Urea & $\mathrm{Kg}$ & 1.960 & 935 & 1.832 .444 & 1.263 & 2.476 .276 \\
\hline 3. Pupuk Phonska & $\mathrm{Kg}$ & 2.600 & 597 & 1.551 .746 & 807 & 2.096 .954 \\
\hline 4. Pupuk SP36 & $\mathrm{Kg}$ & 2.415 & 57 & 138.022 & 77 & 186.516 \\
\hline 5. Pupuk Mutiara & $\mathrm{Kg}$ & 9.081 & 66 & 598.209 & 89 & 808.391 \\
\hline 6. Zat Pengatur Tumbuh & $\mathrm{L}$ & 26.032 & 0,29 & 7.520 & 0,39 & 10.163 \\
\hline \multicolumn{7}{|l|}{ c. Pestisida } \\
\hline 1. Gramaxon & $\mathrm{L}$ & 27.873 & 0,56 & 15.706 & 0,76 & 21.225 \\
\hline 2. Naparon & $\mathrm{Kg}$ & 90.000 & 1 & 90.000 & 1,35 & 121.622 \\
\hline 3. Sidaron & $\mathrm{Kg}$ & 91.959 & 1,79 & 164.943 & 2.42 & 222.896 \\
\hline d. TK Luar Keluarga & $\mathrm{HOK}$ & 35.000 & 59,75 & 2.091 .111 & 80,74 & 2.825 .826 \\
\hline e. Pajak & $\mathrm{Rp}$ & & & 52.103 & & 70.410 \\
\hline f. Pembelian sarung tangan & $\mathrm{Rp}$ & & & 25.873 & & 34.964 \\
\hline g. Sewa Mobil Angkut & $\mathrm{Rp}$ & & & 5.230 .430 & & 7.068 .149 \\
\hline g. Sewa Lahan & $\mathrm{Rp}$ & 1.496 .139 & 0 & 0 & 0 & 0 \\
\hline Total Biaya Tunai & $\mathrm{Rp}$ & & & 14.761 .478 & & 19.947 .944 \\
\hline \multicolumn{7}{|l|}{ Biaya Diperhitungkan } \\
\hline a. TK Dalam Keluarga & $\mathrm{HOK}$ & 35.000 & 10,85 & 379.630 & 14,66 & 513.013 \\
\hline b. Penyusutan alat & $\mathrm{Rp}$ & & & 169.572 & & 229.151 \\
\hline c. Sewa Lahan & $\mathrm{Rp}$ & 1.496 .139 & 0,74 & 1.107 .143 & 1,00 & 1.496 .139 \\
\hline d. Bibit & Batang & $\begin{array}{r}1.470 .100 \\
410\end{array}$ & $26.782,14$ & 10.967 .925 & $36.192,08$ & 14.821 .521 \\
\hline Total Biaya Diperhitungkan & & & & 12.598 .397 & & 17.024 .860 \\
\hline Total biaya & & & & 27.359 .875 & & 36.972 .804 \\
\hline $\begin{array}{l}\text { 3. Pendapatan } \\
\text { I. Pendapatan atas biaya tunai }\end{array}$ & $\mathrm{Rp}$ & & & 34.429 .930 & & 46.526 .933 \\
\hline II. Pendapatan atas biaya total & $\mathrm{Rp}$ & & & 21.831 .533 & & 29.502 .072 \\
\hline \multicolumn{7}{|l|}{ 4. $\mathrm{R} / \mathrm{C}$} \\
\hline $\mathrm{R} / \mathrm{C}$ atas Biaya Tunai & & & & 3,33 & & 3,33 \\
\hline $\mathrm{R} / \mathrm{C}$ atas Biaya Total & & & & 1,80 & & 1,80 \\
\hline
\end{tabular}

